\section{Antithyroglobulin Antibodies in Patients With Differentiated Thyroid Carcinoma: Methods of Detection, Interference With Serum Thyroglobulin Measurement and Clinical Significance}

\begin{abstract}
Antithyroglobulin antibodies ( $\operatorname{Tg} A b)$ were measured using a chemiluminescent immunoassay (ICMA) and an agglutination test. TgAb laboratory and clinical interference with Tg measurements were assessed. The course of TgAb concentration and disease status were compared during 3 years after initial treatment. The agglutination test failed to detect all titers $<10 \mathrm{IU} / \mathrm{mL}$ (ICMA). Interference from TgAb was common at high titers, but even low antibody titers $(<5 \mathrm{IU} / \mathrm{mL}$ ) were able to interfere with Tg measurement. Cases of distant metastases with undetectable Tg (by IRMA) and those apparently free of disease and without thyroid remnants with $\mathrm{Tg}>2 \mathrm{ng} / \mathrm{ml}$ (by RIA) were identified among patients with TgAb. The exogenous Tg recovery test was normal ( $>80 \%)$ by the two methods in $22 \%$ of patients with TgAb and confirmed laboratory interference. Absence of reduction in TgAb levels was a marker of persistent disease. In conclusion, TgAb should be determined by immunoassays; interference with Tg measurements occurred mainly but not always at high concentrations, with a normal Tg recovery test not excluding this interference. The behavior of $\operatorname{TgAb}$ is related to disease persistence or cure. (Arq Bras Endocrinol Metab 2004;48/4:487-492)
\end{abstract}

Keywords: Thyroid carcinoma; Antithyroglobulin antibodies; Thyroglobulin

\section{RESUMO}

Anticorpos Anti-tireoglobulina em Pacientes Com Carcinoma Diferenciado de Tireóide: Métodos de Detecçāo, Interferência Com a Medida da Tireoglobulina Sérica e Significado Clínico.

Anticorpos anti-tireoglobulina (TgAb) foram medidos por um imunoensaio de quimioluminescência (ICMA) e um teste de aglutinação. Avaliamos a interferência clínica e laboratorial dos $\mathrm{TgAb}$ com as medidas de Tg. A evolução da concentração dos TgAb e o estado da doença foram comparados durante 3 anos após o início do tratamento. $O$ teste de aglutinação falhou em detectar todos o títulos $<10 \mathrm{UI} / \mathrm{mL}$ (ICMA). Interferência dos TgAb foi comum com títulos altos, mas mesmo títulos baixos dos anticorpos $(<5 \mathrm{UI} / \mathrm{mL})$ interferiram na medida de Tg. Casos com metástases à distância e Tg indetectável (por IRMA) e aqueles aparentemente livres da doença e sem remanescentes tireoidenos com Tg $>2 \mathrm{ng} / \mathrm{ml}$ (por RIA) foram identificados entre pacientes com TgAb. O teste de recuperação da Tg exógena foi normal (>80\%) por ambos os métodos em $22 \%$ dos pacientes com TgAb, confirmando a interferência laboratorial. Ausência de redução dos níveis de TgAb foi um marcador de persistência da doença. Em conclusão, TgAb deve ser determinada por imunoensaios; interferência com as medidas de Tg ocorreram principalmente mas não somente em altas concentrações, com um teste normal de recuperação de Tg não excluindo esta interferência. $O$ comportamento dos TgAb está relacionado à persistência ou à cura da doença. (Arq Bras Endocrinol Metab 2004;48/4:487492)

\section{artigo original}

Pedro Weslley S. Rosário

Frederico F. Ribeiro Maia

Tales Alvarenga Fagundes

Flávio Palbano Vasconcelos

Ludmilla David Cardoso

Saulo Purisch
Division of Thyroid, Department of Endocrinology and Metabolism, Santa Casa de Belo Horizonte, Belo Horizonte, MG.
Recebido em 05/01/04

Revisado em 05/03/04

Aceito em 20/03/04 
Descritores: Carcinoma de tiróide; Anticorpos antitiroglobulina; Tiroglobulina

$\mathbf{T}$ HYROGLOBUlin ( $\mathrm{TG}$ ) IS THE MAIN serum marker of differentiated thyroid carcinoma, being more sensitive than imaging methods especially when measured during hypothyroidism (1-4) or after stimulation with recombinant thyroid-stimulating hormone $(4,5)$, but interference from antithyroglobulin antibodies $(\mathrm{TgAb})$ might yield falsely high or low serum $\mathrm{Tg}$ values depending on the method used (6-10). The prevalence of these antibodies in patients with differentiated thyroid carcinoma is relatively high (9-12), and methods for their detection and information regarding their interference with $\mathrm{Tg}$ measurement are therefore important. Interference from $\mathrm{TgAb}$ has even been reported for the latest $\mathrm{Tg}$ assays (6), and the value of recovery tests to exclude this interference has been questioned $(6,9,10,13,14)$. Therefore, the identification of circulating $\mathrm{TgAb}$ is extremely important for the interpretation of $\mathrm{Tg}$ results. In addition, $\mathrm{TgAb}$ can be used as markers for the determination of the absence or persistence of the disease $(9,10,12,15-18)$.

The objective of the present study was to assess two methods for $\mathrm{TgAb}$ detection (one immunoassay and one agglutination test) and to determine laboratory and clinically relevant interference of these antibodies with $\mathrm{Tg}$ measurement, the value of exogenous $\mathrm{Tg}$ recovery tests in the exclusion of this interference, and the behavior of $\mathrm{TgAb}$ according to the evolution of the disease.

\section{PATIENTS AND METHODS}

We studied 90 patients (69 women and 21 men; mean age \pm SD: $40.1 \pm 17.2$ years) with differentiated thyroid carcinoma ( 70 with papillary and 20 with follicular carcinomas) after initial treatment by total thyroidectomy and radioactive iodine. The patients were classified according to the presence of $\mathrm{TgAb}$ in at least one of the assays used and according to disease status defined by clinical examination, iodine whole-body scanning and other imaging methods (radiography, ultrasound, tomography and MIBI-scan) (table 1). The large number of patients with cervical disease or distant metastases can be explained by the origin of the patients who were attended by the Nuclear Medicine Service of Santa Casa de Belo Horizonte, where generally only cases with a high probability of disease (ele-
Table 1. Distribution of patients according to disease status and presence of antithyroglobulin antibodies (TgAb).

\begin{tabular}{lcc}
\hline Disease status & $\begin{array}{c}\text { TgAb positive } \\
(\mathbf{n}=\mathbf{2 8})\end{array}$ & $\begin{array}{c}\text { TgAb negative } \\
(\mathbf{n}=\mathbf{6 2})\end{array}$ \\
\hline $\begin{array}{l}\text { Free of disease } \\
\text { and without } \\
\text { thyroid remnants }\end{array}$ & 20 & \\
Distant metastases & 8 & 32 \\
\hline
\end{tabular}

vated $\mathrm{Tg}$ or apparent disease as determined by other methods) are referred for scanning or new treatment. The high prevalence of $\mathrm{TgAb}$ in patients without evidence of disease was explained by the short period between initial therapy and the present investigation (6 months, on average), a time insufficient for a significant decrease in $\mathrm{TgAb}$ concentrations in patients without disease. We are unable to explain the surprising frequency of $\mathrm{TgAb}$ in the sample.

We correlated the two methods for TgAb detection and determined the relationship between laboratory interference with $\mathrm{Tg}$ measurement and antibody concentrations. The interference of $\mathrm{TgAb}$ with $\mathrm{Tg}$ measurement was determined based on the discordance in $\mathrm{Tg}$ measurement in the two methods used (immunoradiometric assay - IRMA and radioimmunoassay - RIA), with interference being defined as a CV higher than the $97.5 \%$ confidence limit obtained for the control group $(9,10)$. Patients apparently free of disease and without thyroid remnants with Tg levels $>2 \mathrm{ng} / \mathrm{ml}$ and patients with distant metastases with undetectable $\mathrm{Tg}$ levels were considered to represent clinically important interference. Only patients with distant metastases and patients apparently free of disease and without thyroid remnants were included.

All sera were submitted to an exogenous $\mathrm{Tg}$ recovery test, with recovery $>80 \%$ being considered normal (value recommended by the manufacturer). $\mathrm{Tg}$ and $\mathrm{TgAb}$ measurements were performed in duplicate in all sera.

Patients with $\mathrm{TgAb}$ were reassessed regarding disease status 2 years later since they had been submitted to surgery or iodine therapy. The course of $\mathrm{TgAb}$ concentration and disease status were compared after this period of time.

\section{Methods}

Tg measurement: Tg was determined after thyroxine withdrawal for 4 weeks, with thyroid-stimulating hormone $>30 \mathrm{mIU} / \mathrm{L}$ in all cases, using the following two methods:

RIA (RIA Tg DSL-2500, Diagnostic Systems Laboratories, Webster, Texas), with an analytical sensiti- 
vity of $0.8 \mathrm{ng} / \mathrm{mL}$ and a functional sensitivity of $1.2 \mathrm{ng} / \mathrm{mL}$, intra-assay CV of $5.4,3$ and $3.6 \%$ for values of 3.7, 13.2 and $102.9 \mathrm{ng} / \mathrm{L}$, respectively, and an interassay precision (interval of 2 months) of 11.1, 2.3 and 3.2\% for values of 3.6, 12.8 and $104.7 \mathrm{ng} / \mathrm{L}$, respectively.

IRMA (ELSA-hTG, CIS bio international, France), with an analytical sensitivity of $0.5 \mathrm{ng} / \mathrm{mL}$ and a functional sensitivity of $0.8 \mathrm{ng} / \mathrm{mL}$, intra-assay precision of $6.6,3.3$ and $2.4 \%$ for values of $4.9,100.8$ and $263.7 \mathrm{ng} / \mathrm{L}$, respectively, and interassay precision (interval of 2 months) of $8,6.9$ and $5.1 \%$ for values of $4.9,223.2$ and $312.9 \mathrm{ng} / \mathrm{L}$, respectively.

Based on the recommendation of the National Academy of Clinical Biochemistry (NACB) (10), the reference value was established for the present population as follows: evaluating 100 euthyroid (TSH 0.5 and $3 \mathrm{mIU} / \mathrm{L}$ ) patients aged less than 40 years without goiter, without a personal or family history of thyroid disease and without $\operatorname{TgAb}$ and TPOAb, the reference value ranged from 3 to $42 \mathrm{ng} / \mathrm{mL}$ for IRMA and from 5 to $45 \mathrm{ng} / \mathrm{mL}$ for RIA, considering 2 SD limits as recommended (10). A hook effect could be excluded using the dilution technique proposed by the NACB (10).

\section{Exogenous Tg Recovery test}

Recovery of Tg in the IRMA was determined according to manufacturer recommendations by adding the sample (patient serum) at a $1: 1$ proportion to the sample standardized by the manufacturer and provided in the kit, which contained $48 \mathrm{ng} / \mathrm{mL} \mathrm{Tg}$. In the case of RIA, we used the manufacturer standard (provided in the kit) at a concentration of $50 \mathrm{ng} / \mathrm{mL} \mathrm{Tg}$. Recovery was calculated as the observed value divided by the expected value, expressed as percentage:

Observed value $\mathrm{x} 100 \mathrm{Tg}$ in the sample (patient serum $)+\mathrm{Tg}$ in the manufacturer standard (kit) 2

Recovery $>80 \%$ was defined as a normal value by the manufacturer.

\section{Determination of TgAb}

$\mathrm{TgAb}$ were measured using a chemiluminescent immunoassay (Chemiluminescent ICMA, Nichols Institute Diagnostic, San Juan Capistrano, CA), with a detection limit of $1 \mathrm{IU} / \mathrm{mL}$, intra- and interassay precision of 8.7 and $5.9 \%$ for values of 2 to $40 \mathrm{IU} / \mathrm{mL}$ (values provided by the manufacturer) and a reference value up to $2 \mathrm{IU} / \mathrm{mL}$, and an agglutination test (Serodia ATG, Fujirebio, Tokyo, Japan), with the lowest value considered to be positive being 1:100 and the highest $1: 6,400,000$, with $100 \%$ reproducibility according to the manufacturer. In the 90 sera tested, intra-assay vari- ability was $<10 \%$ as determined by ICMA in all cases. The agglutination test showed $100 \%$ reproducibility.

\section{Imaging methods}

Whole-body scanning was performed with a tracer dose of $5 \mathrm{mCi}$ iodine-131 during hypothyroidism (thyroid-stimulating hormone $>30 \mathrm{mIU} / \mathrm{L}$ ) after thyroxin withdrawal for 4 weeks and administration of a low iodine diet during the 2 weeks preceding the test. Anterior and posterior images were obtained $72 \mathrm{~h}$ after iodine administration. The imaging methods used in patients with a negative scan for the definition of disease status included cervical ultrasound, contrast-free chest and mediastinum computed tomography and radiography, bone scintigraphy and radiography, and Sestamibi scanning.

\section{Statistical Methods}

The nonparametric Wilcoxon test for paired data was used to correlate the two TgAb detection methods. A $\mathrm{p}$ value $<0.05$ was considered to be significant.

\section{RESULTS}

\section{Methods of TgAb Detection}

The chemiluminescence and agglutination tests showed good correlation $(\mathrm{r}=0.7, \mathrm{p}<0.05)$ (figure 1 ), but titers $<10 \mathrm{IU} / \mathrm{mL}$ at ICMA were systematically negative by the agglutination test.

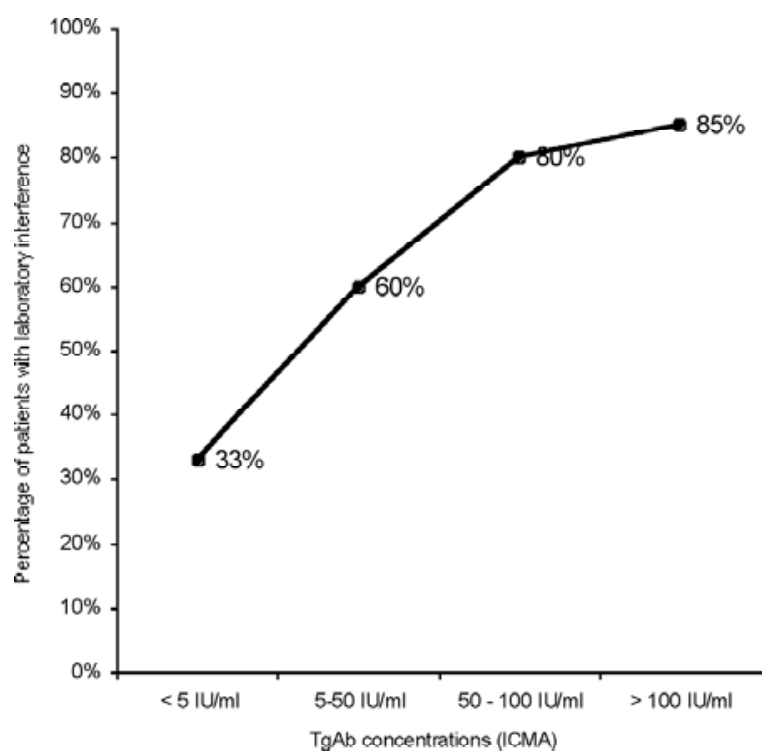

Figure 1. Percentage of patients with antithyroglobulin antibodies (TgAb) showing laboratory interference with Tg measurement. 


\section{Tg Measurement by RIA and IRMA in the Control Group}

Patients with undetectable TgAb by the two methods and detectable $\operatorname{Tg}(\mathrm{n}=38)$ showed levels ranging from 1.1 to $123 \mathrm{ng} / \mathrm{mL}$ by IRMA. The CV between IRMA and RIA ranged from 5 to $48.2 \%($ mean $\pm S D$ : $26 \pm 11.1 \%$ ). The $97.5 \%$ confidence limit in 38 patients with detectable $\mathrm{Tg}$ was a $45 \% \mathrm{CV}$. Tg levels undetectable by IRMA in all 24 samples without $\mathrm{TgAb}$ were also undetectable by RIA ( $100 \%$ agreement).

\section{Laboratory interference of TgAb with $\mathbf{T g}$ Measurement}

Considering interference as a $\mathrm{CV}$ for $\mathrm{Tg}$ measurement (RIA and IRMA) $>45 \%$, interference was present in $18 / 28(64.2 \%)$ of patients with $\mathrm{TgAb}$. Interference was higher at high antibody titers, but one third of the patients with titers $<5 \mathrm{IU} / \mathrm{mL}$ at ICMA showed interference, while no interference was observed in one patient with titer $>100 \mathrm{IU} / \mathrm{mL}$ (figure 1 ).

\section{Clinically Significant interference}

Thirty patients with distant metastases and without $\mathrm{TgAb}$ presented $\mathrm{Tg}$ levels after thyroxine withdrawal $>5 \mathrm{ng} / \mathrm{mL}$ (lowest value $5.6 \mathrm{ng} / \mathrm{mL}$ ) by the two methods. Of the eight patients with distant metastases but with $\mathrm{TgAb}, 4(50 \%)$ had undetectable Tg by IRMA; however, Tg was higher than $>5 \mathrm{ng} / \mathrm{mL}$ in all cases when determined by RIA. In the case of the 32 patients apparently free of the disease and without thyroid remnants without $\mathrm{TgAb}, \mathrm{Tg}$ was undetectable by the two methods in $24(75 \%)$ patients and none of the patients showed values $>2 \mathrm{ng} / \mathrm{mL}$ (highest value $1.8 \mathrm{ng} / \mathrm{mL}$ ). Among the 20 patients with $\mathrm{TgAb}$, in the same condition, $\mathrm{Tg}$ was $>2 \mathrm{ng} / \mathrm{mL}$ in $11(55 \%)$ by RIA and $<2 \mathrm{ng} / \mathrm{mL}$ in all by IRMA. In 11 patients with RIA/IMA discordance $(\mathrm{Tg}>2 \mathrm{ng} / \mathrm{mL}$ by RIA and $<2 \mathrm{ng} / \mathrm{mL}$ by IRMA), the disease status was defined by imaging methods in addition to iodinescan: cervical ultrasound, contrast-free chest and mediastinum computed tomography and radiography, bone scintigraphy and radiography and Sestamibi scanning.

\section{Exogenous Tg Recovery test}

In patients without $\operatorname{TgAb}(\mathrm{n}=62)$, recovery measured by the two methods (RIA and IRMA) exceeded $80 \%$ in all cases irrespective of $\mathrm{Tg}$ concentration. Patients with $\mathrm{TgAb}$ in the absence of laboratory interference showed recovery rates $>80 \%$, but recovery determined by the two methods was also normal in $4 / 18(22 \%)$ patients showing interference and 2/18 (11\%) patients was normal only by RIA.

\section{TgAb and Disease Status}

Of the 20 patients with $\mathrm{TgAb}$ without apparent disease or thyroid remnants, all remained in remission after 2 years. A decline in TgAb levels $(>20 \%)$ was observed in 16 patients, with $\operatorname{TgAb}$ being negative in 8 . Of the 8 patients with distant metastases, 2 achieved complete remission accompanied by a decline in $\mathrm{TgAb}$, and 6 continued to show the disease, with a reduction in $\mathrm{TgAb}$ concentration being observed in only one patient.

\section{DISCUSSION}

Comparison of different methods for $\mathrm{TgAb}$ detection showed that, despite good correlation between the two tests, the immunoassay was more sensitive than the agglutination test, in agreement with the literature (9-12). The latter test can be negative at low antibody titers, typically $<10 \mathrm{IU} / \mathrm{mL}$. Since interference with $\mathrm{Tg}$ measurement can be observed even at these titers, immunoassays are the method of choice for the determination of $\mathrm{TgAb}$ when following up patients with differentiated thyroid carcinoma by $\mathrm{Tg}$ measurement (10).

$\mathrm{TgAb}$ interference with $\mathrm{Tg}$ measurement might cause over- or underestimation depending of the method used (6-10) and is influenced by multiple factors (8). Immunometric assays generally yield underestimated $\mathrm{Tg}$ values, while radioimmunoassays lead to overestimated results $(9,10)$. In the present study, laboratory interference from $\mathrm{TgAb}$ was more frequent at higher titers, but absence of interference at high titers $(>100 \mathrm{IU} / \mathrm{mL})$ and its presence at lower titers $(<5 \mathrm{IU} / \mathrm{mL})$ occurred, as also demonstrated by Spencer and cols. (9). Cases of clinically more significant interference included patients with distant metastases and $\mathrm{Tg}$ immeasurable by IRMA and patients apparently free of the disease and without thyroid remnants with $\mathrm{Tg}$ detectable by RIA. In any case, IRMA underestimated and RIA overestimated Tg values. Thus, Tg levels measurable by IRMA in the presence of $\mathrm{TgAb}$ are highly suggestive of disease persistence or recurrence, but Tg levels measurable by RIA might represent over- or underestimation depending on the method used (10).

The exogenous $\mathrm{Tg}$ recovery test has been proposed for the detection of TgAb interference $(19,20)$, but, in agreement with other studies $(6,9,10,13,14)$, 
we demonstrated here that normal recovery of $\mathrm{Tg}$ in serum containing $\mathrm{TgAb}$ does not exclude interference and this method should therefore not be used for the validation of $\mathrm{Tg}$ measurements. This divergence might be explained by differences in endogenous and exogenous $\mathrm{Tg}$, the use of different isoforms with variable immunoreactivity in the preparation of the test (21), and $\mathrm{TgAb}$ heterogeneity (22).

Thyroidectomy and complete ablation of thyroid remnants with elimination of $\mathrm{Tg}$-producing and, consequently, antigen-producing tissue should lead to the cessation of $\operatorname{TgAb}$ production and the existing antibodies should gradually decline until their complete disappearance. Thus, the persistence of $\mathrm{TgAb}$ for a long period of time after treatment indicates the presence of $\mathrm{Tg}$-producing tissue, in this case with high probability of metastases. On the other hand, patients free of disease tend to be negative for $\mathrm{TgAb}$ on the long term $(9,10,12,15-18)$.

In conclusion, the present study suggests that interference from $\mathrm{TgAb}$ is highly common, mainly but not always at high antibody titers, and is characterized by falsely high or low Tg values determined by RIA and falsely low values determined by IRMA. In addition, $\operatorname{TgAb}$ interference cannot be excluded if the exogenous $\mathrm{Tg}$ recovery test is normal. Since even low antibody titers are able to interfere with $\mathrm{Tg}$ measurement, less sensitive methods such as agglutination tests, which do not detect low titers, should be replaced with more sensitive methods such as immunoassays. In addition, $\mathrm{TgAb}$ can be used as markers for the determination of the absence or persistence of disease.

\section{REFERENCES}

1. Ozata M, Suzuki S, Miyamoto T, Liu RT, Fierro-Renoy F, DeGroot LJ. Serum thyroglobulin in the follow-up of patients with treated differentiated thyroid cancer. J Clin Endocrinol Metab 1994;79:98-105.

2. Schlumberger $M$, Baudin E. Serum thyroglobulin determination in the follow-up of patients with differentiated thyroid carcinoma. Eur J Endocrinol 1998; 138:249-52.

3. Schlumberger MJ. Medical progress-papillary and follicular thyroid carcinoma. N Engl J Med 1998338:297-306.

4. Haugen BR, Pacini F, Reiners C, Schlumberger M, Ladenson PW, Sherman Sl, et al. A comparison of recombinant human thyrotropin and thyroid hormone withdrawal for the detection of thyroid remnant or cancer. J Clin Endocrinol Metab 1999;84:3877-85.
5. Mazzaferri EL, Robbins RJ, Spencer CA, Braverman LE, Pacini F, Wartofsky, et al. A consensus report of the role of serum thyroglobulin as a monitoring method for lowrisk patients with papillary thyroid carcinoma. J Clin Endocrinol Metab 2003;88:1433-41.

6. Mariotti S, Barbesino G, Caturegli P. Assay of thyroglobulin in serum with thyroglobulin autoantibodies: an unobtainable goal? J Clin Endocrinol Metab 1995;80:468-72.

7. Feldt-Rasmussen U, Schlumberger M. European interlaboratory comparison of serum thyroglobulin measurement. J Endocrinol Invest 1988; 11:175-81.

8. Schneider $A B$, Pervos R. Radioimmunoassay of human thyroglobulin: effect of antithyroglobulin autoantibodies. J Clin Endocrinol Metab 1978;47:126-37.

9. Spencer CA, Takeuchi M, Kazarosyan M, Wang CC, Guttler RB, Singer PA, et al. Serum thyroglobulin autoantibodies: Prevalence, influence on serum thyroglobulin measurement, and prognostic significance in patients with differentiated thyroid carcinoma. J Clin Endocrinol Metab 1998;83:1121-7.

10. Laboratory support for the diagnosis and monitoring of thyroid disease. National Academy of Clinical Biochemistry - Professional Association. 2002. 125 pages. http://www.nacb.org

11. Ericsson UB, Christensen SB, Thorell JI. A high prevalence of thyroglobulin autoantibodies in adults with and without thyroid disease as measured with a sensitive solidphase immunosorbent radioassay. Clin Immunol Immunopathol 1985;37:154-62.

12. Kumar A, Shah DH, Shrihari U, Dandekar SR, Vijayan U, Sharma SM. Significance of antithyroglobulin autoantibodies in differentiated thyroid carcinoma. Thyroid 1994;4:199-202.

13. Massart C, Maugendre D. Importance of the Detection Method for Thyroglobulin Antibodies for the Validity of Thyroglobulin Measurements in Sera from Patients with Graves Disease. Clin Chem 2002;48:102-7.

14. Spencer CA. Recoveries cannot be used to authenticate thyroglobulin (Tg) measurements when sera contain Tg autoantibodies. Clin Chem 1996;42:661-3.

15. Pacini F, Mariotti S, Formica N, Elisei R. Thyroid autoantibodies in thyroid cancer: Incidence and relationship with tumor outcome. Acta Endocrinol (Copenh) 1988;119:373-80.

16. Rubello D, Girelli ME, Casara D, Piccolo M, Perin A, Busnardo $B$. Usefulness of the combined antithyroglobulin antibodies and thyroglobulin assay in the follow-up of patients with differentiated thyroid cancer. J Endocrinol Invest 1990;13:737-42.

17. Rubello D, Casara D, Girelli ME, Piccolo M, Busnardo B. Clinical meaning of circulating antithyroglobulin antibodies in differentiated thyroid cancer: a prospective study. J Nucl Med 1992;33:1478-80.

18. Chiovato L, Latrofa F, Braverman LE, Pacini F, Capezzone $M$, Masserini $L$, et al. Disappearance of humoral thyroid autoimmunity after complete removal of thyroid antigens. Ann Intern Med 2003;139:346-51. 
19. Matsubayashi S, Kawai K, Matsumoto Y. The correlation between papillary thyroid carcinoma and lymphocytic infiltration in the thyroid gland. J Clin Endocrinol Metab $1995 ; 80: 3421-4$

20. Schaadt B, Feldt-Rasmussen U, Rasmussen B. Assessment of the influence of thyroglobulin (Tg) autoantibodies and other interfering factors on the use of serum Tg as tumor marker in differentiated thyroid carcinoma. Thyroid 1995;5:165-70.

21. Mariotti S, Cupini C, Giani C. Evaluation of a solid-phase immunoradiometric assay (IRMA) for serum thyroglobulin: effect of anti-thyroglobulin autoantibody. Clin Chim Acta 1982;123:347-55.
22. Schulz R, Bethauser H, Stempka L, Heilig B, Moll A, Hufner $M$. Evidence for immunological differences between circulating and tissue-derived thyroglobulin in men. Eur J Clin Invest 1989;19:459-63.

\section{Endereço para correspondência:}

Pedro Weslley Souza Rosário

Centro de Estudos e Pesquisa

Clinica de Endocrinologia e Metabologia (CEPCEM)

Av. Francisco Sales $1111,5^{\circ}$ andar, Ala D

30150-221 Belo Horizonte, MG

FAX: (31) 3213-0836

e-mail: cepcem.bhz@terra.com.br 